\title{
WHAT DETERMINES THE LOYALTY OF AIRLINE PASSENGERS? FINDINGS OF A QUANTITATIVE DATA-MINING STUDY
}

\section{ŠTO ODREĐUJE LOJALNOST PUTNIKA ZRAKOPLOVOM? REZULTATI KVANTITATIVNE STUDIJE RUDARENJA PODATAKA}

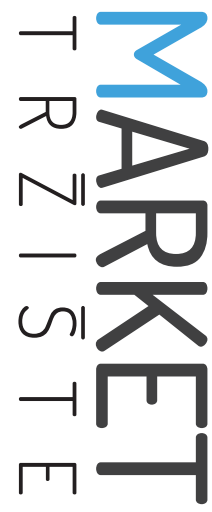

Market-Tržište

Vol. 31, №. 1, 2019, pp. 23-37

UDK 659.127.6:656.7

DOI http://dx.doi.org/10.22598/mt/2019.31.1.23

Original scientific paper

\section{Bình Nghiêm-Phú}

National Institute of Technology, Fukushima College, 30 Taira Kamiarakawa Nagao, Iwaki, Fukushima 970-8034, JAPAN, e-mail: binhnghiem@gmail.com

\begin{abstract}
Purpose - This research study aims to verify a deductive linear model which incorporates the variables to describe perceived airline service quality, perceived value for money, overall satisfaction, and loyalty.
\end{abstract}

Design/Methodology/Approach - Quantitative data for this study were collected from airline passenger reviews posted on airlinequality.com. The database involved 127 airlines of all rankings ( $0,2,3,4$, and 5 stars) and types (traditional and low-cost carriers). Evaluations were provided by all types of travelers (business, couple leisure, family leisure, and solo leisure) in all types of cabins (economy, premium economy, business class, and first class) on both direct and connecting flights.

Findings and implications - Analyses revealed that the human factor (cabin staff service and ground service) is the most important identifier of airline passengers' perceived value for money, overall satisfaction, and loyalty. Traditional products and services (seat, food/beverages, and entertainment) were seen as more important than new ones (Wi-Fi).

Limitations - First, there is no information about passenger profiles. Second, all the measures are composite ones. Third, only six service quality elements were included in the database.

\section{Sažetak}

Svrha - Cilj je ovog rada provjeriti deduktivni linearni model koji uključuje varijable koje opisuju percipiranu kvalitetu zrakoplovne usluge, percipiranu vrijednost za novac, ukupno zadovoljstvo i lojalnost.

Metodološki pristup - Istraživanjem su prikupljeni kvantitativni podatci iz recenzija zrakoplovnih putnika objavljenih na internetskoj stranici airlinequality.com. Baza podataka obuhvatila je 127 zrakoplovnih poduzeća svih rangova (0, 2, 3, 4 i 5 zvjezdica) i tipova (tradicionalni i nisko budžetni). Procjene potječu od svih vrsta putnika (poslovni, parovi koji putuju na odmor, obitelji koje putuju na odmor i samci koji putuju na odmor) u svim vrstama razreda (ekonomskom, premijskom ekonomskom, poslovnom i prvom razredu) te za izravne i za priključne (povezane) letove.

Rezultati i implikacije - Analize su otkrile da je ljudski čimbenik (služba kabinskog osoblja i zemaljska služba) zrakoplovnim putnicima najvažniji identifikator percipirane vrijednosti za novac, ukupnog zadovoljstva i lojalnosti. Tradicionalni proizvodi i usluge (sjedalo, hrana/ piće i zabava) važniji su od novijih (Wi-Fi).

Ograničenja - Prvo, nisu dostupni podaci o profilima putnika. Drugo, sve mjere su kompozitne. Treće, svega 
Originality - This research study is not a case study and its findings can provide meaningful implications for the management of airline service elements with regard to perceived value for money, passenger satisfaction, and passenger loyalty.

Keywords - airline passenger, airline service quality, perceived value for money, satisfaction, loyalty, quantitative datamining je šest elemenata kvalitete usluge uključeno u bazu podataka.

Doprinos - Ovo istraživanje nije studija slučaja i njegovi rezultati mogu pružiti značajne implikacije za upravljanje elementima zrakoplovnih usluga u odnosu na percipiranu vrijednost za novac, zadovoljstvo putnika i lojalnost putnika.

Ključne riječi - zrakoplovni putnik, kvaliteta zrakoplovne usluge, percipirana vrijednost za novac, zadovoljstvo, kvantitativno rudarenje podataka 


\section{INTRODUCTION}

In 1990, for the first time, more than one billion (1.025 billion) passengers were carried by airlines around the world. A quarter of a century after that historical mark, worldwide airlines served 3.696 billion travelers in 2016 (The World Bank, 2018). As demands grow, requests for air service quality are also on the rise. Thus, numerous studies have been conducted to examine passenger evaluations of airline service in order to improve their quality and to win over passenger satisfaction and loyalty. Regarding their method, the majority of previous studies used structured survey techniques to collect passenger evaluations. One of the advantages of this deductive approach is that complicated theoretical models can be built and verified (Akamavi, Mohamed, Pellmann \& Xu, 2015; Basfirinci \& Mitra, 2015). However, the preparation of structured instruments and the collection of quantitative data require a great deal of resources. Alternatively, several studies applied the data-mining technique (to collect and analyze qualitative passenger reviews and/or posts) which included counting and weighing the importance of words/symbols (Liau \& Tan, 2014; Misopoulos, Mitic, Kapoulas \& Karapiperis, 2014). Using this approach, researchers have open access to databases and can generate in-depth understanding of passenger evaluations in an inductive manner. However, the interpretation of the latent meanings of these texts may be biased and incorrect. Moreover, in both cases, the results cannot be generalized due to the nature of the case study method.

This research study introduces another approach to examining passenger evaluations of airline service quality by combining the strengths of the abovementioned methods. Specifically, this study collected quantitative data from passenger reviews to verify a deductive linear model which incorporates the variables describing perceived service quality, perceived value for money, overall satisfaction and loyalty. The database involved 127 airlines of all rankings $(0,2,3,4$, and 5 stars $)$ and types (traditional and low-cost). Evaluations were provided by all types of travelers (business, couple leisure, family leisure, and solo leisure) in all types of cabins (economy, premium economy, business class, and first class) on both direct and connecting flights. Thus, this study is not a case study and its findings can provide meaningful implications for the management of airline service elements with regard to perceived value for money, passenger satisfaction, and passenger loyalty.

\section{LITERATURE REVIEW}

\subsection{Airline service quality and its importance}

Airline service quality is a multi-factor construct. Jacobson (1974), for example, suggested three distinct dimensions of flight comfort (steadiness, sensory aggravation, and activity) and four factors of flight satisfaction (safety, cost-benefit, luxury, and in-flight activity). Later, Westwood, Pritchard and Morgan (2000) identified five elements of airline service from the perspective of businesswomen, including comfort, provisions, safety, staff attitude, and the status of business travelers. A recent analysis by Lim and Tkaczynski (2017) of the expectations of international students resulted in five factors of air service quality: core service, ancillary service, employee service, cabin facility, and service indicators. A more complex study conducted by Wu and Cheng (2013) further revealed that airline service quality can be structured by four main dimensions (interaction quality, physical environment quality, outcome quality, and access quality) with eleven sub-dimensions (conduct, experience, problem-solving, cleanliness, comfort, tangibles, safety and security, waiting time, valence, information, and convenience). Thus, there is no universal consensus on the structure of airline service quality. Different studies have used different scales to measure airline service quality depending on their purpose and settings.

However, a similar finding can be observed in previous studies regarding the importance of 


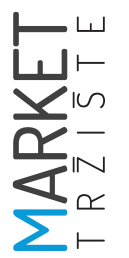

airline service quality in terms of air passengers' perceived value for money, satisfaction, and loyalty (Farooq, Salam, Fayolle, Jaafar \& Ayupp, 2018; Rajaguru, 2016). For example, Kuo and Jou (2014), when surveying air passengers from Taiwan, found that a loss and gain in service quality had significant impacts on perceived value in general, as well as on satisfaction and behavioral intentions or loyalty (repurchase, recommendation, and frequency of use). In addition, perceived value was revealed as important to the formation of satisfaction and behavioral intentions, with satisfaction also being a significant factor in behavioral intentions. In another study involving Taiwanese air passengers, Yang, Hsieh, Li and Yang (2012) found strong evidence to support the positive effects that service quality could have on perceived value and behavioral intentions, and that perceived value could have on behavioral intentions. Nevertheless, it must be noted that perceived value, satisfaction and loyalty of air passengers could also be affected by other forces such as airline image, benefits of frequent flyer programs, price, psychological benefits, and trust (Akamavi et al., 2015; Chen \& Hu, 2013; Mikulić \& Prebežac, 2011; Park, 2010).

Passenger evaluations of airline service quality, however, are not homogenous. For example, Ostrowski, O'Brien and Gordon (1994) reported that business and leisure travelers evaluated airline service quality differently. Specifically, business travelers were less satisfied with what airlines had provided (e.g., carry-on space, aircraft condition, baggage delivery, aircraft interior, and the amount of food). Similarly, Gilbert and Wong (2003) observed that business travelers, holidaymakers and passengers visiting friends/ relatives did not share the same evaluations of airline service quality. Business travelers had higher expectations of lounge service and loyalty programs. Otherwise, holidaymakers and other passengers cared more about the quality of food and beverages, and about in-flight entertainment.
In addition, Fourie and Lubbe (2006) found considerable differences in passenger evaluations of airline service quality between traditional (full-service) and low-cost airlines in South Africa. Unsurprisingly, traditional airlines outdid low-cost airlines in almost all of the elements of service quality, including seat comfort, frequency of flights, seat options, lounge service, and frequent flier programs. Yet, lowcost airlines could provide a slightly better method of payment, although the difference was insignificant at the time of research. A recent study conducted by Kos Koklič, Kukar-Kinney and Vegelja (2017) confirmed these earlier observations. Specifically, full-service airlines proved to perform better in the basic quality elements of airline tangibles (seat comfort, leg space, and entertainment) and staff. However, that study also showed how far low-cost airlines had come since their debut. As evidence, passengers (in Europe in this study) were found to be more satisfied with and to have stronger future intentions (recommendation and repurchase) toward low-cost airlines.

Considering the findings of previous research studies (Fourie \& Lubbe, 2006; Gilbert \& Wong, 2003; Kos Koklič et al., 2017; Ostrowski et al., 1994), it is expected that air passengers may have different evaluations of the service quality of airlines of different rankings (e.g., low- vs. high-ranked airlines) and of different cabin types (e.g., business vs. economy). Also, taking hints from other research (Hansen, 1990; Hsu, Hsu \& Li, 2007), it appears relevant to assume that passengers on direct flights may have different evaluations of air service quality compared to those on connecting flights since the latter have to go through more hassle and have greater need for pre- and in-flight services.

\subsection{Measurement of airline service quality}

The research on airline service quality is mostly quantitative, so data gathered from air passengers using structured instruments are quantitatively analyzed. Robledo (2001) was one of the 
first researchers to apply the SERVQUAL (SERVice QUALity) model to investigate airline service quality (tangibles, reliability, responsiveness, assurance, and empathy). Tsaur, Chang and Yen (2002) employed the fuzzy set theory, the Analytic Hierarchy Process (AHP) method and the Technique for Order Preference by Similarity to Ideal Solution (TOPSIS) to analyze evaluations of the SERVQUAL-based airline service characteristics. Specifically, researchers would start with the collection of the data, go on to weigh the service quality criteria (AHP) and measure performance (fuzzy), and would conclude by ranking service quality (TOPSIS). In another study, Chen and Chang (2005) implemented an expectation-performance analysis to determine the so-called satisfiers and dissatisfiers of airline service quality, while Wong and Chung (2007) applied a decision tree analysis to differentiate air passengers based on their income, membership, trip goal, satisfaction, and perceived image, among other factors. In their study, Martín, Román and Espino (2008) employed the experimental method in examining passenger preferences of airline service. Specifically, Martín and others (2008) conducted a stated preference choice game, in which their respondents could choose their preferred answers from among those offered using a mobile device. The experiment was designed to give the respondents a somewhat realistic setting and to collect more meaningful responses for the consequent analysis.

Otherwise, only a few studies adopted a qualitative method (e.g., interview) to examine the air passengers' evaluations of airline service (Chan, 2014; Westwood et al., 2000). Recently, several researchers have collected and analyzed user generated content (e.g., Tweets) to get an understanding of the airline service factors that make passengers satisfied or unsatisfied (Liau \& Tan, 2014; Misopoulos et al., 2014). These efforts have helped diversify the literature on airline service quality. However, they are too scarce and the in-depth and uninduced nature of the data should be further exploited.

\section{METHOD}

\subsection{Data collection and coding}

This research study applied a quantitative data-mining method to achieve its objectives. A portal run by Skytrax named airlinequality.com was chosen as the source of the data used. On airlinequality.com, passengers and/or users can write reviews about airports, airlines, lounges, and seats (qualitative data) and rate the quality elements of such products and services (quantitative data). Several researchers have used the qualitative data found on the portal to investigate airline and airport services (Bogicevic, Yang, Bilgihan \& Bujisic, 2013; Hossain, Ouedraogo \& Rezania, 2011), but there has been no attempt to employ the quantitative data.

For the purpose of this study, all the reviews written in English and their corresponding ratings of airline service posted between July 2014 and August 2016 were collected ( $n=3,216$ ). The six airline quality elements (seat comfort, cabin staff service, food and beverages, in-flight entertainment, ground service, and Wi-Fi and connectivity) and value for money were rated on a five-point scale, while the overall evaluation was given on a ten-point scale (where 1 represents the least favorable evaluation and 5 or 10, respectively, the most favorable evaluation); the intention to recommend was rated on a dummy scale (with no/ yes answers coded as 0/1). In addition to these explicit variables, some reviewers also expressed their intention to reuse the airline service in their reviews. Therefore, the variable of intention-to-reuse was also coded using the content analysis method (Elo \& Kyngäs, 2008). The coding of the intention-to-reuse variable (no/yes, coded as 0/1) only involved obvious expressions (e.g., "I would fly with them again", "we will not use them again in the future"). The practice was repeated several times until no coding error and/or miss-counting could be found. This was done to ensure that intra-coder reliability was met (Given, 2008).

After that, 816 units of data (25.37\%), which included all the service quality, value for money, overall evaluation, intention to recommend, and 
intention to reuse variables were extracted from the initial pool to serve as the database for the study. The data were grouped by types of travelers (business, couple leisure, family leisure, and solo leisure), cabin types (business class, economy class, first class, and premium economy class), routes (connecting and direct), airlines (low-cost and traditional), and stars $(0,2,3,4,5)$ of the airlines examined $(0=$ no ranking and $5=$ highest ranking; there was no 1-star airline). These data keep track of 127 airlines around the world (see Appendix).

\subsection{Hypotheses}

Based on the existing literature and the availability of the data, the following hypotheses $(H)$ were developed and tested:

H1: Passenger evaluation of airline service quality significantly affects their perceived value for money, overall satisfaction, and loyalty.

H2: Passenger evaluation of perceived value for money significantly affects their overall satisfaction and loyalty.

H3: Passenger overall satisfaction with airline service quality significantly affects their loyalty.

H4: Passenger evaluations of airline service quality, perceived value for money, overall satisfaction, and loyalty differ between/among the (a) types of travelers, (b) cabin types, (c) route types, (d) airline stars, and (e) traditional and low-cost airlines.

\subsection{Data analysis}

With the exception of $\mathrm{H} 4$, which was verified by means of an independent sample $t$-test and the ANOVA analysis of variance in SPSS, the first three hypotheses were tested using the structural equation modeling (SEM) technique computed in Amos. The reasons for choosing SEM is twofold. First, SEM allows the verification of all the related hypotheses simultaneously. Second, SEM facilitates the analysis of loyalty as an unobservable variable (which is structured by the two variables of intention to recommend and intention to reuse). As an alternative to SEM, the regression analysis methods (e.g., hierarchical regression analysis) may be applied. However, the hypotheses and the two intention variables must be estimated separately.

In reality, the testing of $\mathrm{H} 1, \mathrm{H} 2$, and $\mathrm{H} 3$ involves nine variables (overall evaluation was treated as overall satisfaction). Eight of them are observable variables (six quality elements, value for money, and overall satisfaction). Only one, loyalty, is an unobservable variable. The actual sample of this study ( $n=813$ ) is, therefore, sufficient to conduct a reliable SEM analysis. The actual subjects-to-parameters ratio of 90.33 well exceed the ratio of 5-10 suggested by Kline (1998). On an additional note, exploratory analysis revealed that the skew values of all the observable variables were below 1.0, and their kurtosis values were below 2.0. Considering the large size of the sample, the data can be considered as normally distributed (Kim, 2013). However, the reviewers were rather more disloyal than loyal (intention to recommend: mean value $=0.34$, standard deviation $=0.475$; intention to reuse: mean value $=0.33$, standard deviation $=0.472$ )

Finally, the overall fit of the structural model was assessed with reference to Schermelleh-Engel, Moosbrugger and Müller (2003). Specifically, all the selected indices were above the acceptable thresholds, which include Chi-square $=6.574(p$ $=0.475)$, Chi-square/Degree of freedom $=0.939$ $(<2.0)$, SRMR (Standardized Root Mean Squared Residual) $=0.002(<0.05)$, GFI (Goodness-of-Fit Index) $=0.998$ (> 0.95), AGFI (Adjusted Goodnessof-Fit-Index) $=0.987$ (> 0.90), NFI (Normed Fit Index $)=0.999$ (> 0.95), CFI (Comparative Fit Index) $=1.000(>0.97)$ and RMSEA (Root Mean Square Error of Approximation) $=0.000(<0.5)$. Since the majority of the variables in the structural model are composite variables, the indices of multivariable SME analysis (e.g., average variance extracted, composite reliability, discriminant reliability, and convergence reliability) are not reported.

\section{FINDINGS}

The results of the testing of $\mathrm{H1}, \mathrm{H} 2$, and $\mathrm{H} 3$ are provided in Table 1. Accordingly, "Wi-Fi and con- 
nectivity" is the only service quality variable that did not significantly affect either perceived value for money or overall satisfaction. Among the remaining variables, the contributions of "ground service", "seat comfort", and "food and beverages" are stronger than the distributions of "cabin staff service" and "in-flight entertainment." Perceived value for money is the most important identifier of overall satisfaction, with overall satisfaction being the most significant predictor of passenger loyalty. "Cabin staff service" is the only service quality element that could generate a significant impact on loyalty. Consequently, $\mathrm{H} 1$ and $\mathrm{H} 2$ were supported, while H3 was partially supported (Figure 1).

TABLE 1: Correlations among service quality, perceived value for money, overall satisfaction, and loyalty

\begin{tabular}{|l|c|c|c|c|}
\hline Variables & Mean & Value for money & Overall satisfaction & \begin{tabular}{c} 
Loyalty (LY) \\
\hline Seat comfort (SC)
\end{tabular} \\
\hline Cabin staff service (CS) & 3.78 & $\begin{array}{c}\beta=0.266 \\
(p=0.000)\end{array}$ & $\begin{array}{c}\beta=0.401 \\
(p=0.000)\end{array}$ & $\begin{array}{c}\beta=0.013 \\
(p=0.068)\end{array}$ \\
\hline Food and beverages (FB) & 2.55 & $\begin{array}{c}\beta=0.110 \\
(p=0.000)\end{array}$ & $\begin{array}{c}\beta=0.259 \\
(p=0.000)\end{array}$ & $\begin{array}{c}\beta=0.034 \\
(p=0.000)\end{array}$ \\
\hline In-flight entertainment (IE) & 2.52 & $\begin{array}{c}\beta=0.076 \\
(p=0.017)\end{array}$ & $\begin{array}{c}\beta=0.287 \\
(p=0.000)\end{array}$ & $\begin{array}{c}\beta=-0.006 \\
(p=0.446)\end{array}$ \\
\hline Ground service (GS) & 2.62 & $\begin{array}{c}\beta=0.358 \\
(p=0.000)\end{array}$ & $\begin{array}{c}\beta=0.113 \\
(p=0.016)\end{array}$ & $\begin{array}{c}\beta=-0.007 \\
(p=0.338)\end{array}$ \\
\hline Wi-Fi/connectivity (WF) & 2.17 & $\begin{array}{c}\beta=0.050 \\
(p=0.108)\end{array}$ & $\begin{array}{c}\beta=-0.018 \\
(p=0.698)\end{array}$ & $\begin{array}{c}\beta=0.004 \\
(p=0.597)\end{array}$ \\
\hline Value for money (VM) & 2.72 & & $\begin{array}{c}\beta=0.913 \\
(p=0.000)\end{array}$ & $\begin{array}{c}\beta=0.034 \\
(p=0.000)\end{array}$ \\
\hline Overall satisfaction (OS) & 4.30 & & & $\begin{array}{c}\beta=0.096 \\
(p=0.000)\end{array}$ \\
\hline
\end{tabular}

Source: Author's calculation

FIGURE 1: Associations among variables

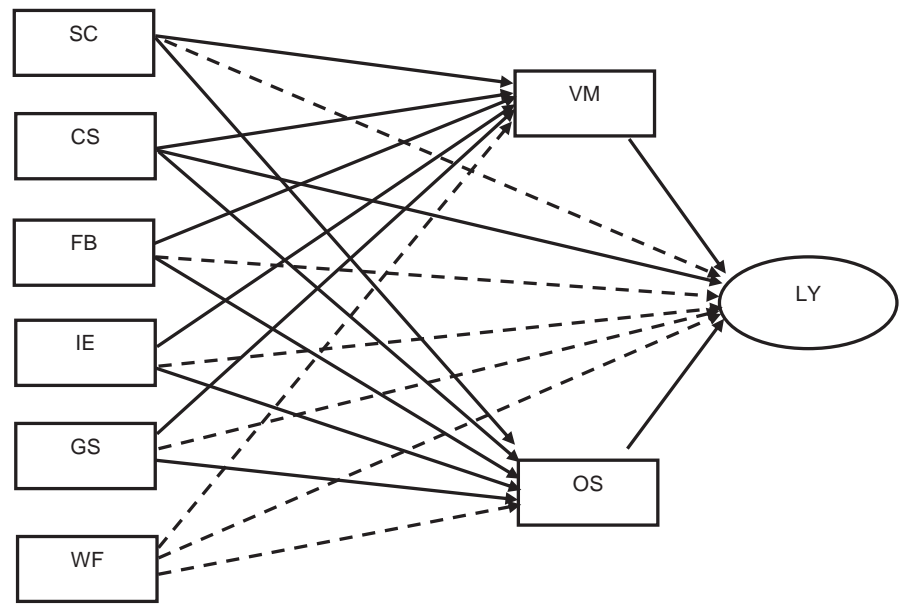

Note: Solid lines represent significant correlations. Dashed lines represent insignificant correlations.

Source: Author's drawing 
Further analyses revealed that $\mathrm{H} 4$ was also supported (Table 2). Among the four types of passengers, solo leisure travelers were the most generous evaluators, while business and family leisure travelers were the most ungenerous ones (Table 3). In addition, with regard to the four types of cabins, business and first-class passengers were the happiest when recalling their experiences, while those in the economy class were the least happy (Table 4). Similarly, fourand five-star airlines were seen as being able to provide the best services, value for money, and overall satisfaction, consequently, passengers tend to be more loyal to these airlines (Table 6). On the other hand, the services provided by three-star and no-star airlines were almost indifferent, while those of two-star airlines were found to be the worst. Moreover, traditional airlines were perceived as providing better services than low-cost airlines (Table 7), and the services during connecting flights were better evaluated than those during direct flights (Table 5).

TABLE 2: Comparison of service quality, perceived value for money, overall satisfaction, and loyalty

\begin{tabular}{|l|c|c|c|c|c|c|}
\hline Variables & Mean & Travelers $^{\mathbf{a}}$ & Cabins $^{\mathbf{b}}$ & Flights $^{\mathrm{c}}$ & Stars $^{\mathbf{d}}$ & Airlines $^{\mathbf{e}}$ \\
\hline Seat comfort & 2.78 & $\begin{array}{c}\mathrm{F}=4.806 \\
(p=0.003)\end{array}$ & $\begin{array}{c}\mathrm{F}=17.823 \\
(p=0.000)\end{array}$ & $\begin{array}{c}t=-1.942 \\
(p=0.053)\end{array}$ & $\begin{array}{c}\mathrm{F}=17.261 \\
(p=0.000)\end{array}$ & $\begin{array}{c}t=-4.156 \\
(p=0.000)\end{array}$ \\
\hline Cabin staff service & 3.02 & $\begin{array}{c}\mathrm{F}=6.214 \\
(p=0.000)\end{array}$ & $\begin{array}{c}\mathrm{F}=8.963 \\
(p=0.000)\end{array}$ & $\begin{array}{c}t=-2.260 \\
(p=0.024)\end{array}$ & $\begin{array}{c}\mathrm{F}=15.595 \\
(p=0.000)\end{array}$ & $\begin{array}{c}t=-0.298 \\
(p=0.766)\end{array}$ \\
\hline Food and beverages & 2.55 & $\begin{array}{c}\mathrm{F}=3.452 \\
(p=0.016)\end{array}$ & $\begin{array}{c}\mathrm{F}=17.107 \\
(p=0.000)\end{array}$ & $\begin{array}{c}t=-4.259 \\
(p=0.000)\end{array}$ & $\begin{array}{c}\mathrm{F}=27.417 \\
(p=0.000)\end{array}$ & $\begin{array}{c}t=-4.427 \\
(p=0.000)\end{array}$ \\
\hline In-flight entertainment & 2.52 & $\begin{array}{c}\mathrm{F}=2.399 \\
(p=0.067)\end{array}$ & $\begin{array}{c}\mathrm{F}=16.161 \\
(p=0.000)\end{array}$ & $\begin{array}{c}t=-4.764 \\
(p=0.000)\end{array}$ & $\begin{array}{c}\mathrm{F}=44.950 \\
(p=0.000)\end{array}$ & $\begin{array}{c}t=-7.389 \\
(p=0.000)\end{array}$ \\
\hline Ground service & 2.62 & $\begin{array}{c}\mathrm{F}=6.649 \\
(p=0.000)\end{array}$ & $\begin{array}{c}\mathrm{F}=5.800 \\
(p=0.001)\end{array}$ & $\begin{array}{c}t=-0.770 \\
(p=0.442)\end{array}$ & $\begin{array}{c}\mathrm{F}=20.149 \\
(p=0.000)\end{array}$ & $\begin{array}{c}t=-1.991 \\
(p=0.047)\end{array}$ \\
\hline Wi-Fi/connectivity & 2.17 & $\begin{array}{c}\mathrm{F}=3.099 \\
(p=0.026)\end{array}$ & $\begin{array}{c}\mathrm{F}=7.589 \\
(p=0.000)\end{array}$ & $\begin{array}{c}t=-1.940 \\
(p=0.053)\end{array}$ & $\begin{array}{c}\mathrm{F}=20.915 \\
(p=0.000)\end{array}$ & $\begin{array}{c}t=-3.624 \\
(p=0.000)\end{array}$ \\
\hline Value for money & 2.72 & $\begin{array}{c}\mathrm{F}=9.156 \\
(p=0.000)\end{array}$ & $\begin{array}{c}\mathrm{F}=6.124 \\
(p=0.000)\end{array}$ & $\begin{array}{c}t=-2.164 \\
(p=0.031)\end{array}$ & $\begin{array}{c}\mathrm{F}=15.430 \\
(p=0.000)\end{array}$ & $\begin{array}{c}t=-2.420 \\
(p=0.016)\end{array}$ \\
\hline Overall satisfaction & 4.30 & $\begin{array}{c}\mathrm{F}=9.199 \\
(p=0.000)\end{array}$ & $\begin{array}{c}\mathrm{F}=12.176 \\
(p=0.000)\end{array}$ & $\begin{array}{c}t=-1.827 \\
(p=0.068)\end{array}$ & $\begin{array}{c}\mathrm{F}=22.432 \\
(p=0.000)\end{array}$ & $\begin{array}{c}t=-2.663 \\
(p=0.008)\end{array}$ \\
\hline Recommend & 0.34 & $\begin{array}{c}\mathrm{F}=8.629 \\
(p=0.000)\end{array}$ & $\begin{array}{c}\mathrm{F}=7.899 \\
(p=0.000)\end{array}$ & $\begin{array}{c}t=-1.457 \\
(p=0.146)\end{array}$ & $\begin{array}{c}\mathrm{F}=16.373 \\
(p=0.000)\end{array}$ & $\begin{array}{c}t=-1.919 \\
(p=0.056)\end{array}$ \\
\hline Reuse & 0.33 & $\begin{array}{c}\mathrm{F}=8.639 \\
(p=0.000)\end{array}$ & $\begin{array}{c}\mathrm{F}=7.476 \\
(p=0.000)\end{array}$ & $\begin{array}{c}t=-1.507 \\
(p=0.132)\end{array}$ & $\begin{array}{l}\mathrm{F}=13.894 \\
(p=0.000)\end{array}$ & $\begin{array}{c}t=-2.048 \\
(p=0.041)\end{array}$ \\
\hline
\end{tabular}

Note:

a. Types of travelers: business ( $n=120)$, couple leisure $(n=240)$, family leisure $(n=204)$, solo leisure $(n=252)$

b. Types of cabins: business class $(n=127)$, economy class $(n=662)$, first class $(n=23)$, premium economy class $(n=44)$

c. Types of flights: connecting $(n=311)$, direct $(n=503)$

d. Stars: $0(n=62), 2(n=33), 3(n=426), 4(n=213), 5(n=82)$

e. Airlines: low-cost $(n=189)$, traditional $(n=627)$

Source: Author's calculation 
TABLE 3: Comparison of traveler types

\begin{tabular}{|c|c|c|c|c|c|c|}
\hline Variables & $\begin{array}{l}\text { Business }^{a} \\
(n=120)\end{array}$ & $\begin{array}{l}\text { Couple } \\
\text { leisure }{ }^{b} \\
(n=240)\end{array}$ & $\begin{array}{l}\text { Family } \\
\text { leisure }^{c} \\
(n=204)\end{array}$ & $\begin{array}{c}\text { Solo } \\
\text { leisure }^{d} \\
(n=252)\end{array}$ & $\mathbf{F}$ & $\boldsymbol{p}$ \\
\hline Seat comfort & 2.64 & $2.63^{d}$ & $2.68^{d}$ & $3.05^{b, c}$ & 4.806 & 0.003 \\
\hline Cabin staff service & $2.75^{d}$ & $2.92^{d}$ & $2.89^{d}$ & $3.35^{a, b, c}$ & 6.214 & 0.000 \\
\hline Food and beverages & 2.45 & 2.45 & 2.43 & 2.79 & 3.452 & 0.016 \\
\hline In-flight entertainment & 2.47 & 2.44 & 2.38 & 2.73 & 2.399 & 0.067 \\
\hline Ground service & $2.16^{b, d}$ & $2.68^{a}$ & 2.51 & $2.87^{\mathrm{a}}$ & 6.649 & 0.000 \\
\hline Wi-Fi/connectivity & 2.11 & 2.12 & $2.01^{d}$ & $2.39^{c}$ & 3.099 & 0.026 \\
\hline Value for money & $2.31^{d}$ & $2.65^{d}$ & $2.58^{d}$ & $3.10^{a, b, c}$ & 9.156 & 0.000 \\
\hline Overall satisfaction & $3.48^{d}$ & $4.16^{d}$ & $3.90^{d}$ & $5.15^{a, b, c}$ & 9.199 & 0.000 \\
\hline Recommend & $0.25^{d}$ & $0.30^{d}$ & $0.30^{d}$ & $0.46^{a, b, c}$ & 8.629 & 0.000 \\
\hline Reuse & $0.22^{d}$ & $0.31^{d}$ & $0.28^{d}$ & $0.45^{a, b, c}$ & 8.639 & 0.000 \\
\hline
\end{tabular}

Note: Superscripted letters represent the respondents whose perceptions differed significantly from the subsample's evaluation.

Source: Author's calculation

TABLE 4: Comparison of cabin types

\begin{tabular}{|c|c|c|c|c|c|c|}
\hline Variables & $\begin{array}{l}\text { Business } \\
\text { class }^{a} \\
(n=127)\end{array}$ & $\begin{array}{l}\text { Economy } \\
\text { class }^{b} \\
(n=662)\end{array}$ & $\begin{array}{c}\text { First } \\
\text { class }^{c} \\
(n=23)\end{array}$ & $\begin{array}{l}\text { Premium } \\
\text { economy }{ }^{d} \\
(n=44)\end{array}$ & $\mathbf{F}$ & $p$ \\
\hline Seat comfort & $3.47^{b}$ & $2.59^{a, c}$ & $3.57^{b}$ & 2.98 & 17.823 & 0.000 \\
\hline Cabin staff service & $3.58^{b}$ & $2.88^{a}$ & 3.43 & 3.25 & 8.963 & 0.000 \\
\hline Food and beverages & $3.28^{b}$ & $2.36^{a, c}$ & $3.26^{b}$ & 2.73 & 17.107 & 0.000 \\
\hline In-flight entertainment & $3.24^{b}$ & $2.32^{a}$ & 3.09 & 2.95 & 16.161 & 0.000 \\
\hline Ground service & $3.03^{b}$ & $2.50^{a}$ & 3.13 & 2.86 & 5.800 & 0.001 \\
\hline Wi-Fi/connectivity & $2.57^{b}$ & $2.05^{a}$ & 2.74 & 2.55 & 7.589 & 0.000 \\
\hline Value for money & $3.22^{b}$ & $2.60^{a}$ & 2.91 & 2.80 & 6.124 & 0.000 \\
\hline Overall satisfaction & $5.71^{b}$ & $3.92^{a}$ & 5.39 & 5.07 & 12.176 & 0.000 \\
\hline Recommend & $0.51^{b}$ & $0.30^{a}$ & 0.43 & 0.41 & 7.899 & 0.000 \\
\hline Reuse & $0.50^{b}$ & $0.29^{a}$ & 0.43 & 0.41 & 7.476 & 0.000 \\
\hline
\end{tabular}

Note: Superscripted letters represent the respondents whose perceptions differed significantly from the subsample's evaluation.

Source: Author's calculation 
TABLE 5: Comparison of direct and connecting flights

\begin{tabular}{|l|c|c|c|c|}
\hline Variables & $\begin{array}{c}\text { Direct flights } \\
(\mathbf{n}=\mathbf{5 0 3})\end{array}$ & $\begin{array}{c}\text { Connecting flights } \\
(\mathbf{n = 3 1 1 )}\end{array}$ & $\mathbf{T}$ & $\boldsymbol{p}$ \\
\hline Seat comfort & 2.70 & 2.90 & -1.942 & 0.053 \\
\hline Cabin staff service & 2.93 & 3.17 & -2.260 & 0.024 \\
\hline Food and beverages & 2.38 & 2.82 & -4.259 & 0.000 \\
\hline In-flight entertainment & 2.32 & 2.84 & -4.764 & 0.000 \\
\hline Ground service & 2.59 & 2.67 & -0.770 & 0.442 \\
\hline Wi-Fi/connectivity & 2.10 & 2.30 & -1.940 & 0.053 \\
\hline Value for money & 2.63 & 2.86 & -2.164 & 0.031 \\
\hline Overall satisfaction & 4.13 & 4.58 & -1.827 & 0.068 \\
\hline Recommend & 0.32 & 0.37 & -1.457 & 0.146 \\
\hline Reuse & 0.31 & 0.37 & -1.507 & 0.132 \\
\hline
\end{tabular}

Source: Author's calculation

TABLE 6: Comparison of airline stars

\begin{tabular}{|c|c|c|c|c|c|c|c|}
\hline Variables & $\begin{array}{l}0 \text { star }^{a} \\
(n=62)\end{array}$ & $\begin{array}{l}2 \text { star }^{b} \\
(n=33)\end{array}$ & $\begin{array}{c}3 \text { star }^{c} \\
(n=426)\end{array}$ & $\begin{array}{c}4 \text { star }^{d} \\
(n=213)\end{array}$ & $\begin{array}{l}5 \text { star }^{\mathrm{e}} \\
(\mathrm{n}=82)\end{array}$ & $\mathbf{F}$ & $\boldsymbol{p}$ \\
\hline Seat comfort & $2.37^{d, e}$ & $1.76^{c, d, e}$ & $2.60^{b, d, e}$ & $3.15^{a, b, c}$ & $3.46^{a, b, c}$ & 17.261 & 0.000 \\
\hline Cabin staff service & $2.98^{e}$ & $2.36^{d, e}$ & $2.77 \mathrm{~d}, \mathrm{e}$ & $3.26^{b, c, e}$ & $4.00^{a, b, c, d}$ & 15.595 & 0.000 \\
\hline Food and beverages & $2.37 \mathrm{~d}, \mathrm{e}$ & $1.67 \mathrm{~d}, \mathrm{e}$ & $2.21 \mathrm{~d}, \mathrm{e}$ & $3.07 a, b, c$ & $3.46^{a, b, c}$ & 27.417 & 0.000 \\
\hline $\begin{array}{l}\text { In-flight } \\
\text { entertainment }\end{array}$ & $1.82^{\mathrm{d}, \mathrm{e}}$ & $1.15^{c, d, e}$ & $2.17^{b, d, e}$ & $3.19^{a, b, c}$ & $3.63^{a, b, c}$ & 44.950 & 0.000 \\
\hline Grol & & & & & & & 0.000 \\
\hline Wi-Fi/connectivity & $1.82 \mathrm{~d}, \mathrm{e}$ & $1.24 \mathrm{~d}, \mathrm{e}$ & $1.94^{d, e}$ & $2.56^{a, b, c}$ & $3.02^{a, b, c}$ & 20.915 & 0.000 \\
\hline Value for money & $2.66^{e}$ & $1.82^{d, e}$ & $2.48^{d, e}$ & $3.03^{b, c}$ & $3.57^{a, b, c}$ & 15.430 & 0.000 \\
\hline Overall satisfaction & $4.00^{e}$ & $2.15^{d, e}$ & $3.64^{d, e}$ & $5.20^{b, c, e}$ & $6.50^{a, b, c, d}$ & 22.432 & 0.000 \\
\hline Recommend & $0.27^{\mathrm{e}}$ & $0.09 \mathrm{~d}, \mathrm{e}$ & $0.27^{d, e}$ & $0.43^{b, c, e}$ & $0.65^{a, b, c, d}$ & 16.373 & 0.000 \\
\hline Reuse & $0.29^{e}$ & $0.09 \mathrm{~d}, \mathrm{e}$ & $0.27 \mathrm{~d}, \mathrm{e}$ & $0.40 \mathrm{~b}, \mathrm{c}, \mathrm{e}$ & $0.62^{a, b, c, d}$ & 13.894 & 0.000 \\
\hline
\end{tabular}

Note: Superscripted letters represent the respondents whose perceptions differed significantly from the subsample's evaluation. Source: Author's calculation

TABLE 7: Comparison of low-cost and traditional airlines

\begin{tabular}{|c|c|c|c|c|}
\hline Variables & $\begin{array}{l}\text { Low-cost airlines } \\
\qquad(n=189)\end{array}$ & $\begin{array}{l}\text { Traditional airlines } \\
\qquad(n=627)\end{array}$ & $\mathbf{t}$ & $p$ \\
\hline Seat comfort & 2.41 & 2.89 & -4.156 & 0.000 \\
\hline Cabin staff service & 2.99 & 3.03 & -0.298 & 0.766 \\
\hline Food and beverages & 2.15 & 2.67 & -4.427 & 0.000 \\
\hline In-flight entertainment & 1.86 & 2.72 & -7.389 & 0.000 \\
\hline Ground service & 2.43 & 2.68 & -1.991 & 0.047 \\
\hline Wi-Fi/connectivity & 1.86 & 2.27 & -3.624 & 0.000 \\
\hline Value for money & 2.49 & 2.79 & -2.420 & 0.016 \\
\hline Overall satisfaction & 3.74 & 4.47 & -2.663 & 0.008 \\
\hline Recommend & 0.29 & 0.36 & -1.919 & 0.056 \\
\hline Reuse & 0.28 & 0.35 & -2.048 & 0.041 \\
\hline
\end{tabular}

Source: Author's calculation 


\section{DISCUSSION}

Researchers have observed that passengers have low loyalty toward airlines (Ostrowski et al., 1994). The findings of this study, interestingly, support that observation. Specifically, the positive correlations between loyalty and its significant antecedents mean that passengers are disloyal because they do not perceive much value for money and are not satisfied with airline service. Thus, in order to strengthen passenger loyalty, airlines need to improve the quality of their services, especially the quality of crew members. On an additional note, cabin staff service was the only service quality element that could distinguish five-star airlines from all others (four-star or less). This element, as suggested by Babbar and Koufteros (2008), includes four sub-elements of individual attention, helpfulness, courtesy, and promptness. All of them were found to have a significant impact on passenger satisfaction.

Cabin staff service, however, is not the most important quality element when it comes to passengers' overall satisfaction and perceived value for money. The most significant one is ground service. This outcome contrasts the findings of a research study by Saha and Theingi (2009), in which ground staff service was the least important identifier of passenger satisfaction, and was exceeded by flight schedules, flight attendants, and tangible cues. This result also is different from the findings of Ringle, Sarstedt and Zimmermann (2011), showing ground service to be less important to passenger satisfaction than capability and in-flight services but more important than safety conditions. However, it should be noted that the measures and the populations of the latter studies are different, which may explain the difference in the findings as well. Practically, ground service is a combination of many sub-services provided both before and after the flights, among others including the ticketing, baggage delivery, information and guidance, check-in, security, immigration, food and beverages, shopping, and customs. The first and the last impressions that passengers have of an airline begin and end with its ground service. Thus, the success or failure of the ground service provided to passengers may have a major impact on the overall experience and/or their evaluation. Ground service, however, is jointly delivered by many providers, for example, airports, airlines, delivery companies, security and customs units, and shop staff. Thus, a consistent and high-quality service needs the active and responsible participation of all the stakeholders involved (Nghiêm-Phú \& Suter, 2017). To make this true, total quality management (Hackman \& Wageman, 1995) should be applied to unite the efforts of the different stakeholders to achieve the common purpose of delivering good products and services.

Together with ground service, seat comfort, food and beverages, and in-flight entertainment are other significant identifiers of passengers' perceived value for money and overall satisfaction. The results showed that traditional and high-ranked airlines could provide these services and products better than low-cost and low-ranked airlines. Moreover, passengers flying in first class and business class can doubtlessly enjoy better services and products than those in the economy class. These outcomes proved that although low-cost and no-frills (i.e., no essential onboard services) airlines are on the rise, traditional and full-service airlines and their products can still survive and grow. The main reason is that the airline passenger market is not a homogenous one (Teichert, Shehu \& von Wartburg, 2008). Business passengers may want to fly with low-cost airlines (Mason, 2001), while low-cost airlines' passengers can pay for extra services on no-frills flights (Correia, Pimpão \& Tão, 2012). Thus, although price may be the most important factor when considering a flight and/ or an airline for many passengers, service quality is nevertheless as important for many others. However, the significance of each service quality element is not the same. Seat comfort is more important than food and beverages, and the latter are more important than entertainment

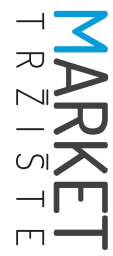


options. It is these elements that distinguish traditional from low-cost airlines, as well as frills from no-frills flights. However, in both cases, the availability of $\mathrm{Wi}-\mathrm{Fi}$ and connectivity is not an important factor to passengers' perceived value for money and overall satisfaction in this period. Wi-Fi service, which was launched in August 2008, is still a new one (Gogo LLC., 2016). Until now, only a few airlines have provided in-flight Wi-Fi (Elliott, 2016). Thus, passengers may not be familiar with this service yet.

The findings of this study, however, do not only provide implications for airlines but for passengers as well. While airlines can be happier when serving solo leisure passengers, all passengers can consider the following options about airlines. Specifically, when their conditions allow, passengers may and/or should fly with four- and five-star airlines and/or in business- or first-class cabins. Traditional and frills airlines are always a better option than low-cost and no-frills ones. In other cases, flying with a no-star airline may be more comfortable than flying with a twostar airline. When passengers have time and are not overly concerned about taking transits, connecting flights are also to be considered.

\section{CONCLUSION}

Applying a quantitative datamining approach, the present research study revealed that the human factor (cabin staff service and ground service) is the most important identifier of airline passengers' perceived value for money, overall satisfaction, and loyalty. Traditional products and services (seat, food/beverages, and entertainment) are more important to passengers than newer ones (Wi-Fi). Considering the representativeness of the database, these findings are meaningful to the worldwide airline industry over a certain period (2014-2016).

Regarding its method, this study illustrated that quantitative data mining can be implemented without too many interpreting and coding procedures. However, this method has several limitations of its own. First, there is no information about passenger profiles. Consequently, this study could not examine the impact that the socio-demographic characteristics can have on passenger evaluations. Second, all the measures are composite ones. In other words, the reflective indicators of each measure are not considered. Third, as only six service quality elements were included in the database, other variables might be missing.

To continue this current effort, future studies can quantitatively data mine customer reviews to take advantage of these open sources. A similar research design can be replicated over a fiveyear period to see changes in the contribution of each service quality element to the definition of passengers' perceived value for money, overall satisfaction, and loyalty. Structured-survey research, which can help gather socio-demographic information of passengers and other service quality indicators, should not be neglected. However, large-scale collaboration is needed to obtain generalizable databases.

\section{References}

1. Akamavi, R. K., Mohamed, E., Pellmann, K., \& Xu, Y. (2015). Key determinants of passenger loyalty in the low-cost airline business. Tourism Management, 46, 528-545.

2. Babbar, S., \& Koufteros, X. (2008). The human element in airline service quality: Contact personnel and the customer. International Journal of Operations \& Production Management, 28(9), 804-830.

3. Basfirinci, C., \& Mitra, A. (2015). A cross cultural investigation of airlines service quality through integration of Servqual and the Kano model. Journal of Air Transport Management, 42, 239-248.

4. Bogicevic, V., Yang, W., Bilgihan, A., \& Bujisic, M. (2013). Airport service quality drivers of passenger satisfaction. Tourism Review, 68(4), 3-18. 
5. Chan, J. K-L. (2014). Understanding the meaning of low airfare and satisfaction among leisure air travellers using Malaysian low-cost airlines. Journal of Vacation Marketing, 20(3), 211-223.

6. Chen, F-Y., \& Chang, Y-H. (2005). Examining airline service quality from a process perspective. Journal of Air Transport Management, 11(2), 79-87.

7. Chen, P-T., \& Hu, H-H. (2013). The mediating role of relational benefit between service quality and customer loyalty in airline industry. Total Quality Management \& Business Excellence, 24(9/10), 1084-1095.

8. Correia, A., Pimpão, A., \&Tão, M. (2012). Willingness to pay for frills when travelling with low-cost airlines. Tourism Economics, 18(6), 1161-1174.

9. Elliott, C. (2016). These airlines have the best wi-fi in the world. Fortune. Available at: http://fortune.com/2016/01/14/airlines-wifi-internet/ (Retrived December 315t, 2016).

10. Elo, S., \& Kyngäs, H. (2008). The qualitative content analysis process. Journal of Advanced Nursing, 62(1), 107-115.

11. Farooq, M. S., Salam, M., Fayolle, A., Jaafar, N., \& Ayupp, K. (2018). Impact of service quality on customer satisfaction in Malaysia airlines: A PLS-SEM approach. Journal of Air Transport Management, 67, 169-180.

12. Fourie, C., \& Lubbe, B. (2006). Determinants of selection of full-service airlines and low-cost carriers - A note on business travellers in South Africa. Journal of Air Transport Management, 12(2), 98-102.

13. Gilbert, D., \& Wong, R. K-C. (2003). Passenger expectations and airline services: A Hong Kong based study. Tourism Management, 24(5), 519-532.

14. Given, L. M. (2008). The SAGE encyclopedia of qualitative methods. Thousand Oaks, CA: Sage.

15. Gogo LLC. (2016). Availabel at: www.gogoair.com/history (Retrieved December 315t, 2016).

16. Hackman, J. R., \& Wageman, R. (1995). Total quality management: Empirical, conceptual, and practical issues. Administrative Science Quarterly, 40(2), 309-342.

17. Hansen, M. (1990). Airline competition in a hub-dominated environment: An application of noncooperative game theory. Transportation Research Part B: Methodological, 24(1), 27-43.

18. Hossain, M. M., Ouedraogo, N., \& Rezania, D. (2011). A consumer perspective of service quality in the airline industry. International Journal of Business and Technopreneurship, 1(1), 1-14.

19. Hsu, C-I., Hsu, C-C., \& Li, H-C. (2007). Flight-delay propagation, allowing for behavioural response. International Journal of Critical Infrastructures, 3(3/4), 301-326.

20. Jacobson, I. D. (1974). The comfort and satisfaction of air travelers-basis for a descriptive model. Human Factors: The Journal of the Human Factors and Ergonomics Society, 16(1), 46-55.

21. Kim, H-Y. (2013). Statistical notes for clinical researchers: Assessing normal distribution (2) using skewness and kurtosis. Restorative Dentistry \& Endodontics, 38(1), 52-54.

22. Kline, R. B. (1998). Principles and practices of structural equation modeling. New York, NY: The Guilford Press.

23. Kos Koklič, M., Kukar-Kinney, M., \& Vegelja, S. (2017). An investigation of customer satisfaction with low-cost and full-service airline companies. Journal of Business Research, 80, 188-196.

24. Kuo, C-W., \& Jou, R-C. (2014). Asymmetric response model for evaluating airline service quality: An empirical study in cross-strait direct flights. Transportation Research Part A: Policy and Practice, 62, 63-70.

25. Liau, B. Y., \& Tan, P. P. (2014). Gaining customer knowledge in low cost airlines through text mining. Industrial Management \& Data Systems, 114(9), 1344-1359.

26. Lim, S. S., \& Tkaczynski, A. (2017). Origin and money matter: The airline service quality expectations of international students. Journal of Hospitality and Tourism Management, 31, 244-252. 
27. Martín, J. C., Román, C., \& Espino, R. (2008). Willingness to pay for airline service quality. Transport Reviews, 28(2), 199-217.

28. Mason, K. J. (2001). Marketing low-cost airline services to business travellers. Journal of Air Transport Management, 7(2), 103-109.

29. Mikulić, J., \& Prebežac, D. (2011). What drives passenger loyalty to traditional and low-cost airlines? A formative partial least squares approach. Journal of Air Transport Management, 17(4), 237240.

30. Misopoulos, F., Mitic, M., Kapoulas, A., \& Karapiperis, C. (2014). Uncovering customer service experiences with Twitter: The case of airline industry. Management Decision, 52(4), 705-723.

31. Nghiêm-Phú, B., \& Suter, J. R. (2017). Airport image: An exploratory study of McCarran International Airport. Journal of Air Transport Management, 67, 72-84.

32. Ostrowski, P. L., O'Brien, T. V., \& Gordon, G. L. (1994). Determinants of service quality in the commercial airline industry: Differences between business and leisure travelers. Journal of Travel \& Tourism Marketing, 3(1), 19-48.

33. Park, J-W. (2010). The effect of frequent flyer programs: A case study of the Korean airline industry. Journal of Air Transport Management, 16(5), 287-288.

34. Rajaguru, R. (2016). Role of value for money and service quality on behavioural intention: A study of full service and low cost airlines. Journal of Air Transport Management, 53, 114-122.

35. Ringle, C. M., Sarstedt, M., \& Zimmermann, L. (2011). Customer satisfaction with commercial airlines: The role of perceived safety and purpose of travel. Journal of Marketing Theory and Practice, 19(4), 459-472.

36. Robledo, M. A. (2001). Measuring and managing service quality: Integrating customer expectations. Managing Service Quality: An International Journal, 11(1), 22-31.

37. Saha, G. C., \& Theingi, A. (2009). Service quality, satisfaction, and behavioural intentions - A study of low-cost airline carriers in Thailand. Managing Service Quality, 19(3), 350-372.

38. Schermelleh-Engel, K., Moosbrugger, H., \& Müller, H. (2003). Evaluating the fit of structural equation models: Tests of significance and descriptive goodness-of-fit measures. Methods of Psychological Research Online, 8(2), 23-74.

39. Teichert, T., Shehu, E., \& von Wartburg, I. (2008). Customer segmentation revisited: The case of the airline industry. Transportation Research Part A: Policy and Practice, 42(1), 227-242.

40. The World Bank (2018). Air transport, passengers carried. Available at: https://data.worldbank.org/ indicator/IS.AIR.PSGR (Retrieved December 25 $\left.{ }^{\text {th }}, 2017\right)$.

41. Tsaur, S-H., Chang, T-Y., \& Yen, C-H. (2002). The evaluation of airline service quality by fuzzy MCDM. Tourism Management, 23(2), 107-115.

42. Westwood, S., Pritchard, A., \& Morgan, N. J. (2000). Gender-blind marketing: Businesswomen's perceptions of airline services. Tourism Management, 21(4), 353-362.

43. Wong, J-Y., \& Chung, P-H. (2007). Managing valuable Taiwanese airline passengers using knowledge discovery in database techniques. Journal of Air Transport Management, 13(6), 362-370.

44. Wu, H-C., \& Cheng, C-C. (2013). A hierarchical model of service quality in the airline industry. Journal of Hospitality and Tourism Management, 20, 13-22.

45. Yang, K-C., Hsieh, T-C., Li, H., \& Yang, C. (2012). Assessing how service quality, airline image and customer value affect the intentions of passengers regarding low cost carriers. Journal of Air Transport Management, 20, 52-53. 


\section{Appendix: List of airlines}

\begin{tabular}{|c|c|c|c|c|c|}
\hline Airline & Frequency & Airline & Frequency & Airline & Frequency \\
\hline Aegean Airlines & 1 & Etihad Airways & 27 & Ryanair & 6 \\
\hline Aer Lingus & 4 & Eurowings & 1 & Santa Barbara Airlines & 1 \\
\hline Aeroflot Russian Airlines & 1 & EVA Air & 4 & SAS Scandinavian & 4 \\
\hline Aeromexico & 2 & Fiji Airways & 2 & SATA Air Azores & 1 \\
\hline Air Berlin & 3 & Finnair & 3 & SATA International & 1 \\
\hline Air Canada & 10 & Flybe & 1 & Scoot & 6 \\
\hline Air Canada rouge & 32 & flydubai & 1 & SilkAir & 4 \\
\hline Air China & 5 & Freebird Airlines & 1 & Singapore Airlines & 10 \\
\hline Air Europa & 3 & Frontier Airlines & 11 & Small Planet Airlines & 1 \\
\hline Air France & 5 & Garuda Indonesia & 3 & SmartWings & 1 \\
\hline Air India & 3 & Hawaiian Airlines & 6 & South African Airways & 2 \\
\hline Air Malta & 1 & Iberia & 6 & Southwest Airlines & 19 \\
\hline Air Mauritius & 2 & Icelandair & 9 & Spirit Airlines & 23 \\
\hline Air New Zealand & 4 & IndiGo & 1 & SriLankan Airlines & 3 \\
\hline Air Seychelles & 1 & Japan Airlines & 5 & Sun Country Airlines & 1 \\
\hline Air Transat & 10 & Jet Airways & 1 & Sunwing Airlines & 1 \\
\hline Alaska Airlines & 4 & Jetairfly & 1 & Swiss Intl Air Lines & 2 \\
\hline Alitalia & 4 & Jetblue Airways & 11 & TAM Airlines & 3 \\
\hline Allegiant Air & 8 & Jetstar Airways & 3 & TAP Portugal & 5 \\
\hline American Airlines & 93 & Jetstar Asia & 1 & Thai Airways & 5 \\
\hline ANA All Nippon Airways & 4 & KLM Royal Dutch Airlines & 7 & Thai Lion Air & 1 \\
\hline AnadoluJet & 1 & Korean Air & 3 & Thomas Cook Airlines & 2 \\
\hline Asiana Airlines & 3 & Kuwait Airways & 3 & Thomson Airways & 4 \\
\hline Avianca & 4 & La Compagnie & 3 & Tigerair & 1 \\
\hline Bangkok Airways & 1 & LAN Airlines & 1 & Turkish Airlines & 23 \\
\hline British Airways & 25 & LOT Polish Airlines & 5 & Turkmenistan Airlines & 1 \\
\hline Brussels Airlines & 1 & Lufthansa & 8 & Ukraine International & 2 \\
\hline Caribbean Airlines & 1 & Malaysia Airlines & 6 & United Airlines & 79 \\
\hline Cathay Pacific Airways & 5 & Middle East Airlines & 1 & US Airways & 2 \\
\hline Cebu Pacific & 1 & Monarch Airlines & 1 & VietJet Air & 1 \\
\hline China Airlines & 2 & Montenegro Airlines & 1 & Vietnam Airlines & 1 \\
\hline China Eastern Airlines & 4 & Nok Air & 1 & Virgin America & 6 \\
\hline China Southern Airlines & 4 & Norwegian & 10 & Virgin Atlantic & 11 \\
\hline Condor Airlines & 3 & Oman Air & 3 & Virgin Australia & 6 \\
\hline Croatia Airlines & 1 & Pegasus Airlines & 5 & Vistara & 1 \\
\hline Cubana Airlines & 1 & Peruvian Airlines & 1 & Volaris & 5 \\
\hline Delta Air Lines & 32 & Philippine Airlines & 5 & Vueling Airlines & 5 \\
\hline Dragonair & 2 & Qantas Airways & 7 & West Jet Airlines & 12 \\
\hline easyJet & 3 & Qatar Airways & 26 & Wizz Air & 4 \\
\hline Egyptair & 1 & Ravn Alaska & 1 & WOW air & 6 \\
\hline El Al Israel Airlines & 2 & Royal Brunei Airlines & 2 & Xiamen Airlines & 1 \\
\hline Emirates & 45 & Royal Jordanian Airlines & 1 & & \\
\hline Ethiopian Airlines & 1 & Rwandair & 1 & & \\
\hline
\end{tabular}

